\title{
Production Potential of Rubberwood in Malaysia: Its Economic Challenges
}

\author{
Jegatheswaran RATNASINGAM', Geetha RAMASAMY', \\ Florin IORAS², Jake KANER², Lu WENMING ${ }^{3}$ \\ ${ }^{1}$ University Putra Malaysia, Faculty of Forestry, 43400 UPM, Serdang, Selangor, Malaysia; jegaratnasingam@yahoo.com \\ ${ }^{2}$ Buckinghamshire New University, Queen Alexendra Road, High Wycombe, HP11 2JZ Buckinghamshire, England \\ ${ }^{3}$ Chinese Academy of Forestry, Wanshoushan Hou, Haidian District, Beijing 100091, P. R. China
}

\begin{abstract}
Rubberwood (Hevea brasiliensis) has emerged as the most important source of wood raw material in Malaysia. Being a plantation crop, it is regarded as a green and environmental-friendly material that has found applications in almost all sectors of the wood industry. Despite its importance as a socio-economic sector, the future of the rubberwood industry in Malaysia is under scrutiny. The steadily declining rubber cultivation area in the country is raising alarms about the future supply of rubberwood. Although the government provides a replanting subsidy for smallholders, who make up the large proportion of the growers, there is an urgent need to enhance the profitability of rubber growing activities. Efforts to enhance the full recovery of wood biomass available and also expanding the use of rubberwood in high value applications must be pursued rigorously, to arrest the declining interests in rubber cultivation. Policy makers must ensure that rubber cultivation remains economical and the net value of rubberwood is further enhanced through application in non-traditional sectors.
\end{abstract}

Keywords: recovery, rubberwood, supply, sustainability, value added

\section{Introduction}

The rubber industry has become one of the most important socio-economic sectors since Malaysia's independence in 1957. The industry has featured strongly both in terms of foreign exchange earnings as well as rural economic development for the country. The success of the Malaysian rubber industry has become the envy of many in the tropical belt throughout the world, as the country is still regarded as the leader in the field, both in terms of its cultivations as well as its utilization. Despite its success, the rubber industry in Malaysia is losing some of its glitter and among the most notable fact is the rapid rise of neighbouring Indonesia and Thailand as rubber producers in the world. This revelation has indeed some long term implications, as it will affect the long term development of the rubber industry as a whole (Ratnasingam and Scholz, 2009). The purpose of this paper is therefore to review the development of the rubber industry in the country, and highlight the economic challenges faced by the sector as well as to propose possible remedial actions.

\section{Rubberwood supply and processing}

The history of the rubber industry in Malaysia

Sir Henry Wickham is credited as the father of the rubber industry in Malaysia. He brought some seeds to the Kew Garden, United Kingdom from Brazil in 1876.
Some of the seedlings were then transported to the Singapore Botanical Garden through Ceylon (now known as Sri Lanka) in the same year. Archive records showed that the initial cultivation of rubber in Malaysia began in Kuala Kangsar in 1879 (Ratnasingam, 2000).

A mature rubber tree is usually in the range of 20 to 30 $\mathrm{m}$ tall and its diameter can reach up to $30 \mathrm{~cm}$ (Balsiger $e t$ al., 2000). The trunk is generally free of branches until the height of 3 to $10 \mathrm{~m}$ (Lim et al., 2003). With a planting distance of $3 \mathrm{~m}$ by $7 \mathrm{~m}$, the stocking density of rubber trees is usually in the range of 300 - 350 trees per hectare. Rubber trees are now widely planted in 20 countries around the world for the production of latex or natural rubber (Teoh et al., 2011). According to Shigematsu et al. (2011), more than $80 \%$ of total rubber plantation areas in the world are in Asia, with Malaysia, Indonesia and Thailand covering almost $70 \%$ of the total rubber cultivation. Malaysia was the largest producer of rubber in the world until the late 1980's (Balsiger et al., 2000). Indonesia then took over as the biggest rubber cultivator in the world followed by Thailand. Malaysia is currently the $3^{\text {rd }}$ most important country in the world for rubber cultivation (Shigematsu et al., 2011).

\section{Rubberwood as a raw material}

Rubberwood, or rather the wood derived from the trunks of the rubber trees (Hevea brasiliensis) after being felled for replanting, has emerged as the most important 
318

wood raw material in the country. Initially promoted as an alternative source of wood raw material for the wood industry, when logging activities in the natural forests was restricted by the Malaysian government in the mid-1980s, Malaysia has become the most successful country in using rubberwood throughout the world.

The exploitation of rubberwood by the wood industry in Malaysia began with sawn timber processing, mainly for export to India and Sri Lanka, which had a long history in using rubberwood as other timber resources were scarce. In this context, Malaysia became the first country to successfully export rubberwood sawn timber in the late 1970s (Hong and Sim, 1994). From being a waste-wood, rubberwood became an important wood feedstock for the large wood products industry in the country.

Although, the potential of rubberwood for applications in the wood industry had been recognized way back in the 1950s, its inherent low durability and the abundant supply of other wood species from the natural forests hindered the use of rubberwood on a large scale. If it were not for the efforts of the Forest Research Institute of Malaysia (FRIM) and the Malaysian Timber Industry Board (MTIB), rubberwood would not have gained the success it currently commands (Hong and Sim, 1994).

Nevertheless, it must be emphasized that the commercial success of rubberwood as a raw material of international repute is due to the intensive efforts by industrial players such as Masco Corporation, Hong Teak Furniture Industry and UMW Furniture Industries, who championed the use of rubberwood in their knock-down furniture products exported to the United States of America in 1979 (Ratnasingam and Scholz, 2009).

In this context, it is apparent that the public-private partnership in the successful utilization of rubberwood is very evident in the Malaysian context, and is perhaps a feat to be emulated in other rubber growing countries as well.

\section{The supply of rubberwood}

Despite its overwhelming success, the future supply of rubberwood has emerged as a major concern of the wood products industry in the country. In a survey by Ratnasingam and Jalil (2011), 73\% of the wood products manufacturers interviewed were gravely concerned about the seasonality in the supply of rubberwood, and the ever increasing price of the material. Inevitably, most of them are concerned about the declining profit margins for their products, which may have a long term implication on the viability of their business.

The major cause of this trend is the steadily declining rubber cultivation area in the country, fuelled by the low price of latex (natural rubber) and the eagerness of the growers to convert to more profitable crops, particularly oil palm (Teoh et al., 2011). It has been reported that the area under rubber cultivation has shrunk from 1.93 million hectares in 1990 to almost 1.0 million hectares in 2010 (Ratnasingam and Jones, 2011).

The expected internal rate of return (IRR) of $17 \%$ envisaged in rubber cultivation was not realized in most instances, due to fluctuating natural rubber prices in the world market and the increasing cost of labour experienced in rubber cultivation. Ratnasingam and Scholz (2009) have shown that rubber cultivation at best would result in returns of approximately $8 \%$ per annum, provided a yield of $2400 \mathrm{~kg} / \mathrm{ha}$ of natural rubber is realized consistently and the prices of natural rubber stays above the par value.

Inevitably, interests in rubber growing appear to be weaning in the large estates, while smallholders are the predominant players in this sector, although their yield and management are somewhat below par when compared to the professionally managed estates. Large estates in the country, such as Sime Darby, KL Kepong, IOI, Guthrie and Golden Hope are significantly reducing their rubber cultivation areas. In the report by Ratnasingam and Scholz (2009), it was suggested that the subsidy (amounting to US $\$ 2750$ per hectare) provided by the government to the smallholders is absolutely crucial in keeping the industry viable, especially when the urge to revert to the more profitable oil palm is available as an option.

Tab. 1 provides the current industrial demand for rubberwood among the various sectors in the country. It is apparent that almost $35 \%$ of all rubberwood biomass processed remains as waste, which must be exploited efficiently if the industry is to remain competitive in the future.

It is apparent that the use of rubberwood in the Malaysian wood products industry is distorted, and is not close to full and effective utilization of the available biomass. In order to off-set this "distorted demand", there is an urgent need to re-examine the policy and legislative instruments that could be put in place to boost better use of all the available wood resource.

Tab. 1. Demand for rubberwood in Malaysia (2010)

\begin{tabular}{cccc}
\hline Sub-Sector & $\begin{array}{c}\text { Annual processing capacity } \\
\left(\text { million } \mathrm{m}^{3}\right)\end{array}$ & $\begin{array}{c}\text { Processing efficiency } \\
(\%)\end{array}$ & $\begin{array}{c}\text { Apparent waste produced } \\
\left(\mathrm{m}^{3}\right)\end{array}$ \\
\hline Harvesting $($ i) & 5.4 & 40 & 3.2 \\
Sawmilling (ii) & 2.1 & 30 & 1.5 \\
Furniture (iii) & 1.9 & 70 & 0.5 \\
Builders carpentry and joinery $(\mathrm{iv})$ & 0.6 & 90 & 0.1 \\
Panel products $(v)$ & 1.7 & 90 & 0.2 \\
\hline
\end{tabular}

Note: Figures based on study by Ratnasingam and Jones (2011) 
Sustaining the supply of rubberwood for the future

It may be inferred that the sustainable supply of rubberwood in Malaysia is dependent on the economics of its supply, rather than its overall contribution to the socioeconomics of the country. Figure 1 shows the supply situation of rubberwood in the country based on the replanting rate of $3 \%$. It seems that there is sufficient supply of rubberwood to the wood industry in the country, and the reported short supply is unjustified. However, these calculations are based on several assumptions: (i) the replanting activity is carried out as per schedule, (ii) all above ground biomass up to $10 \mathrm{~cm}$ in diameter is extracted from the field, and (iii) waste and residues from the secondary milling activities are used in the panel products sector. However, it has been found that $35 \%$ of the above ground biomass from rubber smallholdings is often left behind due to logistics and transportation reasons (Ratnasingam and Jones, 2011). In a survey reported by Ratnasingam and Scholz (2009), it was found that the average cost of rubberwood biomass per hectare is US\$2000, which approximates to about US $\$ 15$ per $\mathrm{m}^{3}$ of wood biomass. Although rubberwood saw logs can fetch up to US\$ $60 \mathrm{per}^{3}$, the small dimension residues average about US $\$ 20 \mathrm{per}^{3}$. Inevitably, the cost of rubberwood fiber is lower than other wood fiber from the natural forests, suggesting the need for further government interventions if rubberwood production is to be expanded.

Although the government provides a replanting subsidy of US\$2750 per hectare to the smallholders (Shigematsu et al., 2011), there is almost no incentive provided to ensure the highest recovery of the rubberwood biomass available on the field from the replanting activities. Due to the technological constraints associated with the use of mobile sawmills and the higher demand for longer and wider sawn timber, most portable sawmill operators prefer to saw larger diameter logs which provides a better return (Ratnasingam and Jones, 2011). Considering the fact that almost $80 \%$ of the rubber cultivation area in Malaysia is under smallholdings, it is imperative to ensure that the highest possible biomass recovery is achieved from these rubber areas during the replanting activities. This is even more pertinent in rubber smallholdings area as the decision-making among such growers do not always correspond to main stream recommendations, especially when it comes to replanting activities.

From an agronomic perspective, the average growth rate of $15 \mathrm{~m}^{3} / \mathrm{ha} /$ year recorded for rubber areas in the country should be able to sustain the demand for rubberwood from the wood industry, provided the biomass recover is maximized (Shigematsu et al., 2011). Essentially, policy makers should be aware of the shifting interests in rubber cultivation in the country, and implement a framework of incentive schemes not only to boost replanting activities but also to ensure that the rubberwood biomass produced is fully recovered. On the other hand, increasing the value of rubberwood by expanding its applications to high value construction materials as well as fashion accessories may further boost the future of the material.

Fig. 1 provides an analysis of the amount of rubberwood biomass that becomes available on an annual basis in the country. It is apparent that there is sufficient biomass to meet the demand of the various wood product sectors in the country, provided the biomass is fully recovered and utilized efficiently. Perhaps, it is the right time for policy makers to pay greater attention to incentive schemes that will ensure the biomass is fully utilized, in order to over-

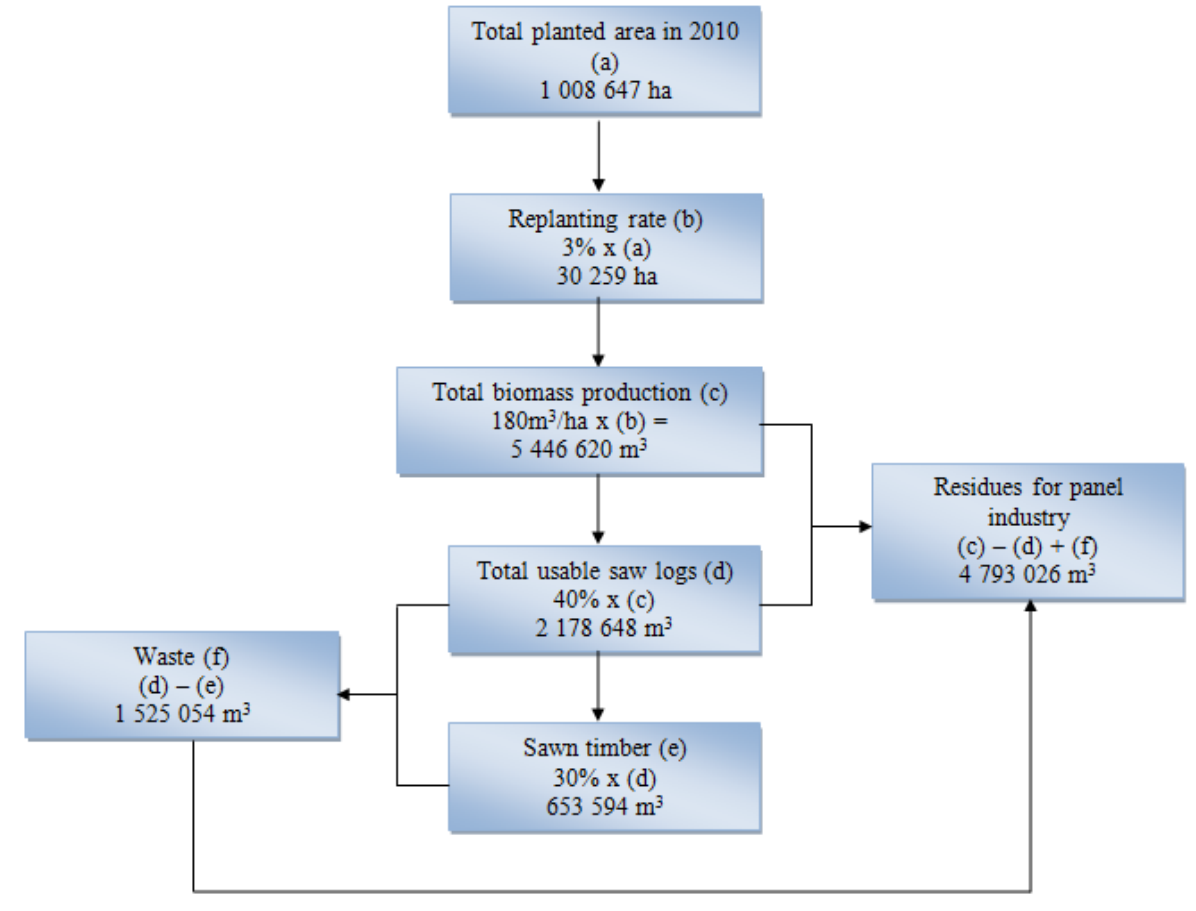

Fig. 1. Rubberwood biomass production and yield status in Malaysia 
320

come the short supply situation faced seasonally in the country.

Based on the data presented in Tab. 1, it is apparent that if the small diameter wood materials are utilized by the panel products manufacturers, the available supply of rubberwood in the country would be sufficient to cope with the needs of the industry. Unfortunately, this is not the case, as many of the panel products manufacturers compete with sawmillers for the saw logs to feed their respective mills, inevitably forcing an ever increasing price of the material.

A study by Shahwahid and Rahim (2009), however found that the production of medium density fibreboard from rubberwood has a conflicting effect on the furniture industry. The resultant competition and the ensuing price war for rubberwood materials among the mills have negatively affected the profitability in the industry. Hence, the wood fibre cost has increased by almost $30 \%$ between 2000 and 2010, and yet, no guarantee is available to the millers ensuring their future supply of the material. Although the Malaysian government has embarked on a large scale compensatory forest plantation program in East Malaysia since 2009, its implementation is mired with uncertainty regarding land issues, quality planting material and incentives. Although, rubber cultivation has been identified as one of the core activity in the program, without the necessary economic incentives and framework for plantation establishments, the anticipated success of the program remains questionable (Ratnasingam and Jones, 2011). As reported previously by several authors (Attah et al., 2009; Ratnasingam et al., 2008 a; Ratnasingam and Scholz, 2009), without a proper policy framework to guarantee the viability of rubber cultivation in the country, the uncertainty surrounding the sustainable supply of rubberwood will remain in the country.

One possible incentive scheme that could be introduced is the "green technology incentive scheme" that rewards manufacturers who use or recycle waste as the feedstock into their manufacturing lines. Although such efforts are already in place in many developed countries, without financial incentives such efforts may not materialize in the country, where the subsidy mentality is very much prevalent even within the large wood products in-

Tab. 2. Possible technologies for the rubberwood industry dustry. In a report by Ratnasingam and Jones (2011) it was suggested that providing an extraction incentive between US $\$ 25$ to US $\$ 40$ per $\mathrm{m}^{3}$ of wood extracted from the field as well as the factory site, would boost the recovery of rubberwood biomass significantly. It was further suggested that this incentive would cost up to an additional US $\$ 250$ million per annum on top of the total subsidy provided to the rubber growers, it would serve as a strong impetus to boost the green status and also reduce the carbon footprint of the rubberwood industry in the country.

\section{Is technology application the key to sustaining the rubberwood supply?}

The rubberwood industry in Malaysia is regarded as highly successful, with export earnings in excess of US\$ 3 billion per annum over the last few years, while providing employment for almost 75,000 people in the country (Ratnasingam and Scholz, 2009).

Intensive research and development $(\mathrm{R} \& \mathrm{D})$ carried out by many agencies over the last few decades have expanded the use of rubberwood to almost every sector of the wood products industry, such as saw milling, medium density fibreboard, particleboard, laminated veneer lumber, plywood, glulam, laminated finger-jointed boards, veneer, cement-bonded board, builders carpentry and joinery, flooring, door, pulp, furniture and even as the medium for mushroom cultivation (Ratnasingam and Scholz, 2009). Tab. 2 provides a summary of the technological developments that could further enhance the use of rubberwood biomass in the various sub-sectors of the wood products industry in the country.

Based on the available statistics from the Statistics Department of Malaysia (2010 and 2011), the amount of rubberwood available in the country is forecasted to range between 5.3 to 6.1 million $\mathrm{m}^{3}$ per annum over the next decade, which is sufficient to fulfil the needs of the wood products manufacturing sector. The forecasted figures shows that the supply of rubberwood in the country should be sufficient to fulfil the demands from the industry, provided wastages are kept under control. It goes to show that the short supply of rubberwood experienced is primarily due to: (i) inefficient processing, (ii) logistical short-comings in recovery activities and (iii) the un-

\begin{tabular}{|c|c|}
\hline Harvesting & $\begin{array}{l}\text { The use of on-site chipper canters would significantly reduce waste and } \\
\text { improve the extraction of small diameter wood materials }\end{array}$ \\
\hline Sawmilling & $\begin{array}{l}\text { The use of wood-mizer technology and the sawing-drying-ripping } \\
\text { technique to boost recovery and minimize defects }\end{array}$ \\
\hline Furniture & The use of optimizers and short-length finger jointer to boost recovery of short length stocks \\
\hline Builders carpentry and joinery & The use optimizers and precision moulders to boost recovery \\
\hline Veneer and plywood & $\begin{array}{l}\text { The application of log steaming techniques and spindle-less chucks to } \\
\text { ensure greater recovery from the small dimension logs }\end{array}$ \\
\hline Panel products & $\begin{array}{l}\text { Full on-site chipping of all materials up to } 10 \mathrm{~cm} \text { in diameter would reduce } \\
\text { logistics cost significantly and also ensure sustainable supply of feedstock }\end{array}$ \\
\hline Fuel & Saw dust and other non-usable waste to be converted into briquettes and pellets for fuel \\
\hline
\end{tabular}




\begin{tabular}{|c|c|}
\hline STRENGTHS & WEAKNESSES \\
\hline $\begin{array}{l}\text { - } \quad \text { most available raw material } \\
\text { - } \quad \text { good working properties } \\
\text { - } \quad \text { widely accepted } \\
\text { - } \\
\text { short rotation wood resource compared to trees from natural forest }\end{array}$ & 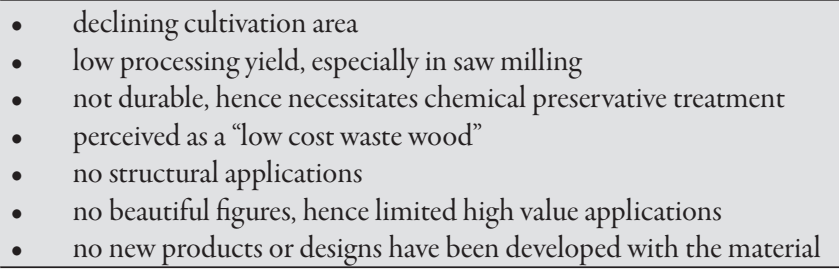 \\
\hline OPPORTUNITIES & THREATS \\
\hline $\begin{array}{l}\text { - technologies can boost recovery and reduce processing waste } \\
\text { - utilization can be extended to structural applications through } \\
\text { stringent quality controls } \\
\text { easily cultivated, and hence growing areas can be rapidly expanded } \\
\text { through high timber yield clones } \\
\text { - ample breeding know-how available in the country to be tapped } \\
\text { incentives could be provided to boost full exploitation of the } \\
\text { resource }\end{array}$ & $\begin{array}{l}\text { - without further value-addition, material will stagnate with its } \\
\text { commodity status } \\
\text { could be easily replaced by other fast growing plantation wood } \\
\text { resource } \\
\text { - fundamental chemical understanding of the material will hamper } \\
\text { its exploitation } \\
\text { the application of chemical preservatives increases its toxicity, which } \\
\text { will impairs its acceptability }\end{array}$ \\
\hline
\end{tabular}

Source: Ratnasingam and Jones (2011)

balanced distribution of the resources throughout the country (Ratnasingam and Scholz 2009; Ratnasingam et al., 2012). In other words, the is a growing necessity to exploit rubberwood to its fullest from every different angle through the appropriate technology, so much so that, without such measures and initiatives, the concern about rubberwood supply will remain persistent with the industry in the country.

\section{The status of rubberwood as a raw material}

The rubberwood industry in Malaysia is almost half a century old, yet questions surrounding the wood resource are very much persistent, especially with regards to its sustainable future supply and improving its processing recovery. Tab. 3 provides an analysis of the current status of rubberwood in terms of its strengths and weaknesses, which will pave the way for deliberation on the resource's future as the most important wood resource in the country.

Studies by Ratnasingam et al. (2007, 2008 b) have shown conclusively that wood species is important as a marketing characteristics of value-added wood products, and in the case of rubberwood products its sales is driven primarily by its low cost. Further, the lack of certified rubberwood resource in the country also affects its credibility as a valuable wood resource for the wood products industry. In essence, the future of rubberwood as a raw material for the wood products industry in Malaysia hinges upon the industry's ability to overcome these hurdles and also exploit the opportunities available in order to change its perceived flagging fortunes.

\section{Economic viability of rubberwood processing in Malaysia}

In a recent study by Ratnasingam and Jones (2011) it was shown that rubberwood cultivation and processing is viable and profitable under the following conditions:

- The minimum volume of biomass (up to $10 \mathrm{~cm}$ ) recovered should be above $180 \mathrm{~m}^{3}$ per hectare;
- The minimum volume of saw logs produced should be $45 \mathrm{~m}^{3}$ per hectare;

- The average cost of saw-logs per $\mathrm{m}^{3}$ should be US\$ 60 ;

- The minimum volume of sawn timber produced should be $15 \mathrm{~m}^{3}$ per hectare;

- The approximate processing cost (excluding preservative treatment and kiln drying costs) should be approximately US $\$ 60$ per $\mathrm{m}^{3}$;

- The average preservative treatment and kiln drying costs should be US 75 per $\mathrm{m}^{3}$, and

- The minimum sawn timber price should be approximately US $\$ 380$ per $\mathrm{m}^{3}$ or more.

It is imperative to also recognize that rubberwood is not widely used as fuel-wood in the country, and hence, all available biomass should be exploited in the industrial sectors. Inevitably, the success of rubberwood as a raw material is simply attributed to its competitive pricing compared to other wood resources, even the imported sources, and unless this competitiveness is maintained, the economics of rubberwood processing may be severely affected.

\section{Conclusion}

The availability of Rubberwood has been driving the success of the wood industry in Malaysia over the last three decades, since the reduced production of saw logs from the natural forests. Despite being a green and renewable wood material, its low profitability to the growers and the apparently low value fetched by the wood resource in the market, are slowly but definitely eroding the interests in rubber cultivation. Although the government is supporting the rubber industry through the provision of subsidies to encourage replanting, without a long-term policy framework to boost the recovery of all available wood biomass from the field and also the factory sites, the sustainable supply of rubberwood for the future will remain a contentious issue. 
322

\section{References}

Attah A, Ioras F, Abrudan IV, Ratnasingam J (2009). The Voluntary Partnership Agreement: The Ghanaian and Malaysian experiences. The International Forestry Review 11(3):311-318.

Balsiger J, Bahdan J, Whiteman A (2000). The Utilization, Processing and Demand for Rubberwood as a Source of Wood Supply. APFC-Working Paper No. APFSOS/WP/50. FAO, Bangkok.

DepartmentofStatistics(2010).AnnualRubberStatistics.http:// www.statistics.gov.my/portal/download_Agriculture/files/ RUBBER/2010/RUBBER_ANNUAL2010.pdf (Accessed 15 October 2011)

Department of Statistics (2011). Rubber Industry's Contribution to National Exports. http://www.statistics.gov.my (Accessed 15 October 2011)

HongLT, Sim HC (Ed). Rubberwood Processing and Utilisation, Forest Research Institute Malaysia, Kuala Lumpur.

Lim SC, Gan KS, Choo KT (2003). The Characteristics, Properties and Uses of Plantation Timbers - Rubberwood and Acacia Mangium. Timber Technology Bulletin 26:1-10

Shahwahid HOM, Rahim ASA (2009). A Preliminary Study of Strategic Competitiveness of MDF Industry in Peninsular Malaysia by Using SWOT Analysis. International Journal of Business and Management 4(8):205-214. http:// www.ccsenet.org/journal/index.php/ijbm/article/ view/1858/3051 (Accessed 16 October 2011)

Ratnasingam J (2000). Rubberwood Supply in Malaysia. Asian Timber 19(9):16-19
Ratnasingam J, Ioras F, Macpherson TH (2007). Influence of Wood Species on the Perceived Value of Wooden Furniture: The Case of Rubberwood. Holz Roh Werkst 65(6):487489.

Ratnasingam J, Macpherson TH, Ioras F (2008 a). An Assessment of Malaysian Wooden Furniture Manufacturers' Readiness to Embrace Chain of Custody (COC) Certification. European Journal of Wood and Wood Products 66(5):339-343.

Ratnasingam J, Macpherson TH, Ioras F, Abrudan IV (2008 b). Chain of Custody Certification among Malaysian wooden furniture manufacturers: status and challenges. The International Forestry Review, Volume 10 (1):23-28.

Ratnasingam J, Scholz F (2009). Rubberwood an Industrial Perspective. World Resource Institute, Washington.

Ratnasingam J, Jalil MH (2011). Rubberwood - Its Future in Malaysia. IFRG Report No. 23, Singapore, 39 p.

Ratnasingam J. Jones ML (2011). Recovery Problems in Rubberwood Plantations. IFRG Report No. 14, Kuala Lumpur, $47 \mathrm{p}$.

Ratnasingam J, Ioras F, Abrudan IV (2012). An evaluation of occupational accidents in the wooden furniture industry - A regional study in South East Asia. Safety Science 50(5):11901195

Shigematsu A, Mizoue N, Kajisa T, Yoshida S (2011). Importance of Rubberwood in Wood Export of Malaysia and Thailand. New Forests 41(2):179-189.

Teoh YP, Don MM, Ujang S (2011). Assessment of the Properties, Utilization and Preservation of Rubberwood (Hevea Brasiliensis): A Case Study in Malaysia. Journal of Wood Science 57(4):255-266. 